\title{
GABA-ergic control of prolactin release in rainbow trout (Oncorhynchus mykiss) pituitaries in vitro
}

\author{
Patrick Prunet, Jean-François Gonnard and Gilles Paboeuf \\ Laboratoire de Physiologie des Poissons, INRA, campus de Beaulieu, 35042 Rennes cedex, France
}

Keywords: prolactin, $\gamma$-aminobutyric acid, perifusion, primary culture, rainbow trout

\begin{abstract}
The involvement of $\gamma$-aminobutyric acid (GABA) in the control of prolactin (PRL) release was investigated in rainbow trout using both perifused pituitary fragments and pituitary cells in primary culture. In our perifusion system, infusion of GABA $\left(10^{-6}\right.$ to $\left.10^{-4} \mathrm{M}\right)$ caused an inhibition of PRL release (between 20 and $40 \%$ ). Administration on perifused pituitary fragments of 3APS, a GABAa agonist, mimicked this inhibitory effect. Moreover, bicuculline, a specific antagonist of GABAa receptors, totally abolished GABA effect. When tested on cultured pituitary cells during $40 \mathrm{~h}$ exposure, GABA $\left(10^{-5} \mathrm{M}\right)$ caused a significant decrease in PRL release (24.5\%). Baclofen, a specific agonist for GABAb receptor tested at $10^{-6}$ and $10^{-5} \mathrm{M}$, also inhibited PRL released from cultured pituitary cells. These results demonstrate that GABA inhibits PRL release by acting directly on pituitary cells and that probably both types of GABA receptor ( $a$ and $b$ ) are involved in this regulation.
\end{abstract}

\section{Résumé}

Nous avons étudié l'implication de l'acide $\gamma$-aminobutirique (GABA) dans le controle de la sécrétion de prolactine (PRL) chez la truite arc-en-ciel en utilisant à la fois des fragments d'hypophyse perifusés et des cellules hypophysaires en culture. Dans notre système de périfusion, le GABA $\left(10^{-6}\right.$ à $\left.10^{-4} \mathrm{M}\right)$ inhibe la libération de PRL (entre 20 et $40 \%$ ). L'administration sur les fragments d'hypophyse périfusés de 3APS, un agoniste des récepteurs GABAa, reproduit ces effets inhibiteurs. De plus, la bicuculline, un antagoniste spécifique des récepteurs de type GABAa, abolie complètement les effets du GABA. Lorsqu'il est testé pendant 40h sur des cellules en culture, le GABA $\left(10^{-5} \mathrm{M}\right)$ réduit de manière significative la libération de PRL $(24.5 \%)$. Le Baclofen, un agoniste spécifique des récepteurs GABAb testé à $10^{-6}$ et $10^{-5} \mathrm{M}$, inhibe aussi la libération de PRL par les cellules en culture. Ces résultats démontrent que le GABA inhibe la libération de PRL en agissant directement sur les cellules hypophysaires et que les 2 types de récepteurs GABA (a et b) sont impliqués dans cette régulation.

\section{Introduction}

In mammals, contradictory findings have been reported regarding the control of pituitary func- tions by $\gamma$-aminobutyric acid (GABA). The presence of two different GABAergic systems in the mediobasal hypothalamus is associated with a dual action of GABA (inhibitory and stimulatory) on 
prolactin (PRL) release (Apud et al. 1989). GABA has been shown to inhibit the secretory activity of PRL cells by acting directly at the levels of anterior pituitary (Enjalbert et al. 1979; Locatelli et al. 1979). Moreover, at the level of hypothalamus, GABA modulates the activity of the tuberoinfundibular dopaminergic system, thus leading to an increase of PRL release (Racagni et al. 1982; McCann et al. 1984).

In teleost fish, little attention has been paid to the control of anterior pituitary functions by GABA. In the goldfish pituitary, radioautographic and immunocytochemical studies demonstrated the presence of a dense GABAergic innervation of both anterior and neurointermediate lobes (Kah et al. 1987b). Moreover, Kah et al. (1987a) provided evidence for direct synaptic contacts between GABA endings and secretory cells. An innervation of pituitary by GABA fibres was also observed in carp (Follenius 1972) and in rainbow trout (Dubourg, P., Gonnet, F. and Kah, O., unpublished data). However, in vitro studies of the control of PRL release by GABA did not show any effect of this neurotransmitter either in tilapia, Sarotherodon mossambicus (Wigham et al. 1977), or in rainbow trout (James and Wigham 1984). In the latter, measurements of PRL levels were performed using an electrophoretic technique which was not demonstrated to be specific for PRL and therefore, results should be interpreted with caution.

In order to bring physiological data which would provide significance to GABAergic innervation of PRL cells in rainbow trout, we undertook to redetermine whether GABA modifies PRL secretion in vitro. This study was performed using two techniques developed for trout in our laboratory: in vitro perifusion of pituitary fragments and primary culture of pituitary cells.

\section{Materials and methods}

\section{Experimental animals}

Immature rainbow trout (Oncorhynchus mykiss) of both sexes were purchased from a freshwater hatch- ery and kept in recirculating tap water at $13^{\circ} \mathrm{C}$ under natural photoperiod.

\section{Perifusion experiments}

The animals were killed between 15:00 and 16:00h and the pars distalis was dissected under the microscope. The pituitary fragments thus obtained were preincubated for $10 \mathrm{~min}$ in culture medium (RPMI-medium-GIBCO/BRL-supplemented with HEPES $20 \mathrm{mM}, \mathrm{NaHCO}_{3} 9 \mathrm{mM}$, penicillin $100 \mathrm{U} / \mathrm{ml}$, fongizone $0.25 \mathrm{~g} / \mathrm{ml}$ and bovine serum albumin $0.3 \%$-fraction V, SIGMA-). The $\mathrm{pH}$ and the osmotic pressure of this medium were adjusted to $\mathrm{pH} 7.4$ and $300 \mathrm{mOsm}$, respectively. The pituitary fragments were placed in the perfusion system (Gonnet et al. 1988) and perfused with the medium described above at low flow rate $(3.6 \mathrm{ml} / \mathrm{h})$ for $16 \mathrm{~h}$ at $15^{\circ} \mathrm{C}$. The following day, flow rate was progressively increased to $25 \mathrm{ml} / \mathrm{h}$. The system was equilibrated for $2 \mathrm{~h}$ before effluent medium was collected as $5 \mathrm{~min}$ fractions during the stabilization period and as 0.75 or $2.5 \mathrm{~min}$ fractions during infusion of the various secretagogues. The fractions collected were frozen at $-20^{\circ} \mathrm{C}$ until assay.

\section{Secretagogues}

GABA, 3-amino-1 propane sulfonic acid (3APS), bicuculline and aminooxyacetic acid were purchased from Sigma Chemical Company.

\section{Primary culture of pituitary cells}

The procedures for preparing dispersed and cultured cells from rainbow trout pituitary glands have already been described in details by Weil et al. (1986) and Le Goff et al. (1992). In these series of culture experiments, pre-treatment with poly-Llysine (Sigma Chemical Company, $5 \mathrm{~g} / \mathrm{cm}^{2}$ ) was applied to culture plates before cell plating. 


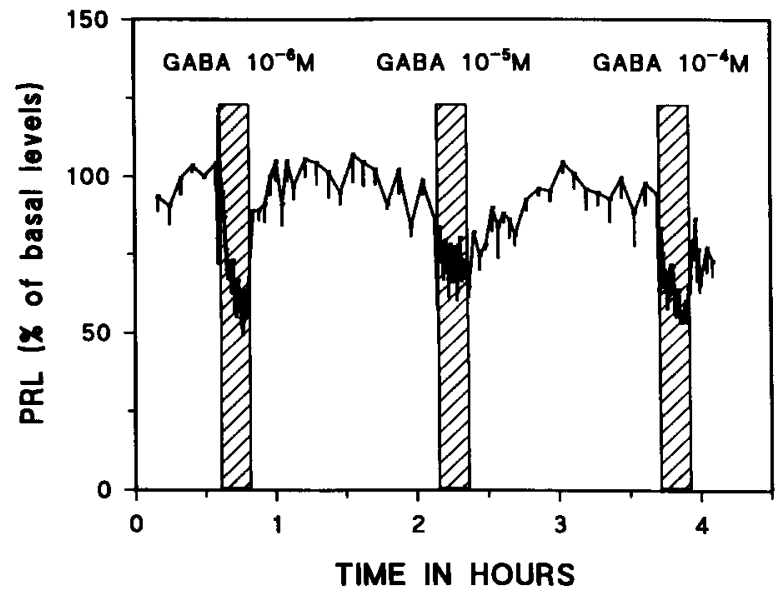

Fig. 1. Effect of increasing concentrations of GABA on PRL secretion by perifused pituitary fragments. After a $16 \mathrm{~h}$ equilibration period GABA was infused for $15 \mathrm{~min}$. Data represent the mean \pm SEM of four independent perifusion experiments. The reference level of PRL release $(100 \%)$ was calculated for each experiment as the mean PRL secretion rate for $\mathbf{3 0}$ min just preceding infusion of the first dose of GABA.

\section{$P R L$ radioimmunoassay}

PRL secreted from perifused pituitary fragments or from cultured pituitary cells was determined using a PRL salmon RIA according to the technique described by Prunet et al. (1985). This RIA has been demonstrated to be specific for measurement of PRL in rainbow trout (Prunet et al. 1985).

\section{Calculation}

The perifusion profiles were calculated and expressed as percentages of basal secretory level. The basal level (indicated as 100\%) was calculated as the mean of three fractions just before the infusion of secretagogues. Each figure represents the mean profile established from four independent experiments. In the primary culture experiments, PRL measurements were subjected to Mann-Witney non-parametric test for comparing the differences between group means. Differences between groups were considered significant if $\mathrm{p}<0.05$.

\section{Results}

\section{Effect of GABA on PRL secretion}

Infusion of different doses of GABA $\left(10^{-7}\right.$ to $10^{-5} \mathrm{M}$ ) on perifused pars distalis which were equilibrated for $90 \mathrm{~min}$ did not lead to consistent changes in PRL secretion (data not shown). However, after an overnight equilibration period, infusion of GABA $\left(10^{-6}\right.$ to $\left.10^{-4} \mathrm{M}\right)$ for $20 \mathrm{~min}$ inhibited PRL release (Fig. 1). This inhibition (between $20 \%$ and $40 \%$ ) occurred just after the onset of GABA administration and the effect was sustained during the rest of the infusion. Variability in the levels of basal PRL secretion observed during perifusion did not allow us to obtain a clear doserelated effect of GABA on PRL secretion.

Effect of GABA on PRL released from pituitary cells in primary culture was also studied. Aminooxyacetic acid (AOAA), a GABA-transaminase inhibitor, was added in the culture medium at the dose of $2.410^{-6} \mathrm{M}$ in order to protect GABA from degradation. When cultured pituitary cells were exposed to GABA during $40 \mathrm{~h}$, a significant decrease $(24.5 \%)$ was observed with the dose $10^{-5} \mathrm{M}$ (Fig. 2). GABA at $10^{-6} \mathrm{M}$ induced a slight but non-significant decrease in PRL release. When GABA was tested for a shorter period of time $(6,12$ or 24h), no significant effect on PRL secretion was observed (data not shown).

\section{Effect of $G A B A$ agonists and antagonist on PRL} secretion

In order to test the specificity of these GABA effects, different agonists or antagonists of the two class of GABA receptors (classified as GABAa and GABAb) were tested on PRL secretion. Administration to perfused pituitary fragments of 3APS $\left(10^{-5} \mathrm{M}\right)$, a GABAa agonist (Nistri and Constani 1979), mimicked the inhibitory effect of GABA (Fig. 3). As shown in Fig. 4, bicuculline $\left(10^{-4} \mathrm{M}\right)$, a specific antagonist of GABAa receptors, totally abolished the inhibitory effect of infused GABA (Fig. 4). Addition of GABA alone served as internal control. Interestingly, infusion of bicuculline 


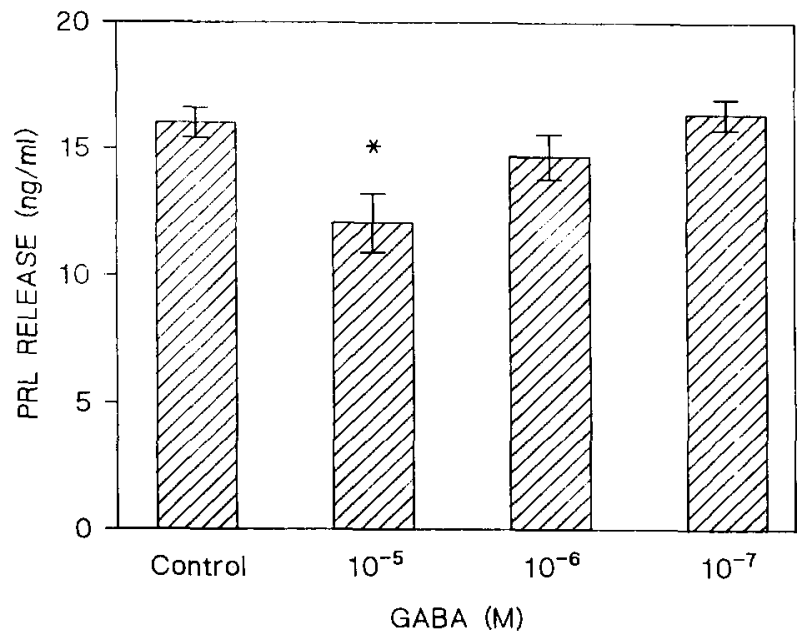

Fig. 2. PRL release from pituitary cells in primary culture after treatment with various concentrations of GABA. Six $\times 10^{4}$ cells/well were initially plated. The treatment was performed 3 days after plating, for $40 \mathrm{~h}$. Values are means \pm SEM $(n=5)$. *p $<0.05$ compared to control.

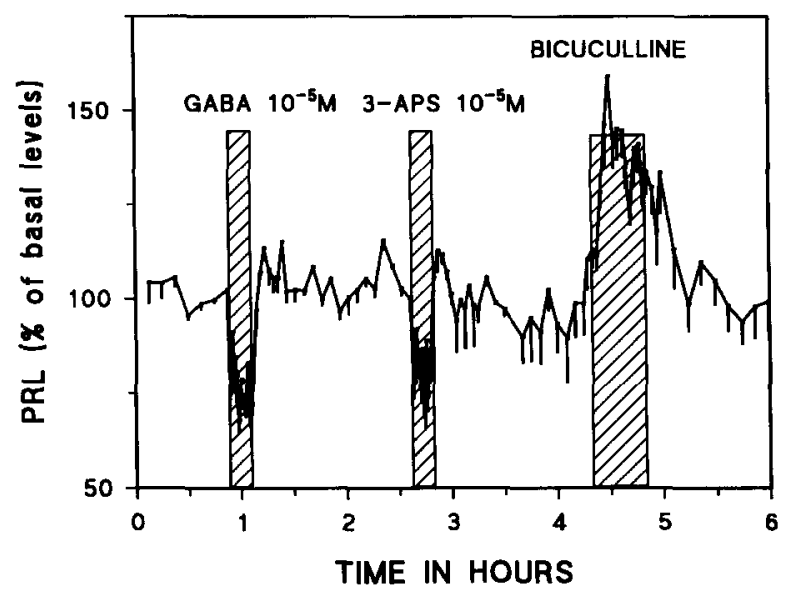

Fig. 3. Effect of GABA $\left(10^{-5} \mathrm{M}\right), 3$ APS $\left(10^{-5} \mathrm{M}\right)$ and bicuculline $\left(10^{-4} \mathrm{M}\right)$ on PRL secretion by perifused rainbow trout pituitaries. After $16 \mathrm{~h}$ equilibration period, GABA and later 3APS were perfused for $20 \mathrm{~min}$, whereas bicuculline was perfused for $30 \mathrm{~min}$. Data were treated as for Figure 1.

$\left(10^{-4} \mathrm{M}\right)$ alone induced an increase of PRL secretion (Fig. 3).

Baclofen, a specific agonist for GABAb receptors, was also tested. When administered to perifused pituitary fragments, baclofen did not show any consistent effects (data not shown). However, when incubated for $40 \mathrm{~h}$ with cultured pituitary cells at concentrations of $10^{-5}$ or $10^{-6} \mathrm{M}$, this

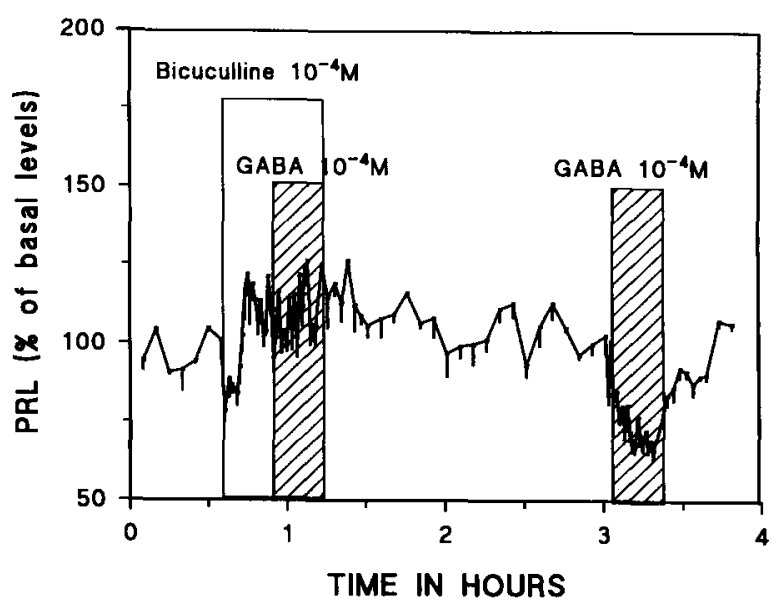

Fig. 4. Effect of GABA $\left(10^{-4} \mathrm{M}\right)$ in the presence or absence of bicuculline $\left(10^{-4} \mathrm{M}\right)$ on PRL secretion by perifused rainbow trout pituitaries. After a $16 \mathrm{~h}$ equilibration period, bicuculline was perfused for $\mathbf{4 0} \mathrm{min}$. Twenty min after the onset of bicuculline administration, GABA was infused for $20 \mathrm{~min}$ in the presence of bicuculline. Data were treated as for Figure 1.

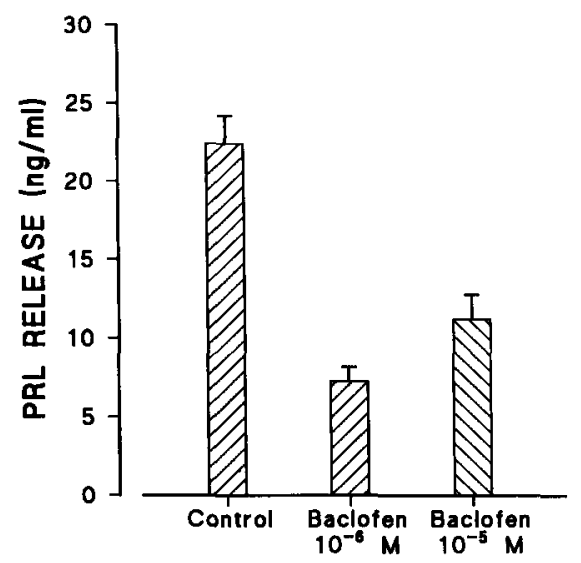

Fig. 5. PRL release after treatment with two different concentrations of baclofen, a GABAb agonist. Six $\times 10^{4}$ cells $/$ well were initially plated. The treatment was performed 3 days after plating for $40 \mathrm{~h}$. Values are means $\pm \operatorname{SEM}(n=5) .{ }^{* *} \mathrm{p}<0.001$ compared to control.

GABAb agonist significantly inhibited PRL secretion (Fig. 5).

\section{Discussion}

In the present study, we provide evidence that GABA is able to inhibit PRL secretion from rain- 
bow trout pituitary in vitro. Moreover, GABA is also able to act directly at the level of the PRL cells, as indicated by the inhibitory effects of GABA on PRL released from cultured pituitary cells. Thus, these results provide physiological significance for the widespread GABAergic innervation described in the goldfish and rainbow trout pituitary, close to the PRL cells (Kah et al. 1987a; Dubourg, P., Gonnet, F. and Kah, O., unpublished data). These results are in agreement with numerous studies in the rat pituitary showing a direct inhibitory control of PRL secretion by GABA (Enjalbert et al. 1979; Locatelli et al. 1979; Racagni et al. 1982; Loeffler et al. 1986).

In our perifusion system, effective doses of GABA which inhibited PRL secretion range between $10^{-6}$ and $10^{-4} \mathrm{M}$. Similar ranges of doses were also used in studies on the effect of GABA on MSH secretion using superfused amphibian intermediate lobes (Adjeroud et al. 1986; Verburg-van Kemenade et al. 1987). Moreover, GABA inhibited PRL released from rat incubated hemipituitaries using doses between $10^{-6}$ and $10^{-5} \mathrm{M}$ (Enjalbert et al. 1979). Interestingly, in our perifusion experiments, infusion of bicuculline, a specific antagonist for GABAa receptor, induced an increase of the basal PRL release. A similar result was observed by Adjeroud et al. (1986) on perifused frog intermediate lobes. This suggests the presence of an endogenous GABA-ergic inhibitory tonus in the perifused tissue. In the present study, such hypothesis is further supported by absence of clear GABA effect when perifused pituitary fragments were only equilibrated for $2 h$ and the necessity of an overnight equilibration period which probably eliminates part of this GABA-ergic tonus. In this context, one would expect that only high doses of GABA would inhibit PRL secretion. Moreover, possibility of metabolization of GABA by GABAtransaminase during our perifusion experiments may also explain why it is necessary to use these doses. In mammals, a high GABA-transaminase activity was localized in the pituitary which was devoid of GAD activity, enzyme responsible for GABA synthesis (Racagni et al. 1979). Finally, in absence of reported values for GABA concentrations which reach PRL cells in fish, it is difficult to conclude whether the doses used in the present study are physiological or not.

More unexpected were our results showing that only a large dose $\left(10^{-5} \mathrm{M}\right)$ of GABA added for 40h was able to inhibit PRL release in cultured pituitary cells. This effect could only be observed after addition of AOAA, an inhibitor of GABAtransaminase, which would protect GABA from degradation (Duvilanski et al. 1985). Moreover, baclofen, a GABAb agonist, incubated in similar conditions appeared to be more potent than GABA as $10^{-6} \mathrm{M}$ dose induced $50 \%$ inhibition of PRL release. This suggests a possible partial degradation of GABA during incubation. Shorter periods of exposure to GABA were tested without leading to significant effect on PRL release. Such delay in the response of trout PRL cells in primary culture has already been described when studying the effects of somatostatin (Le Goff et al. 1992). This situation, not observed with GH cells, was suggested by Le Goff et al. (1992) to be associated with a particular behaviour of cultured PRL cells which seem to be under a dominant stimulatory control by hypothalamus in rainbow trout (Gonnet et al. 1989; Yada et al. 1991).

The use of high flow rates and short collection time in our perifusion experiments have led to a clear description of the PRL response to GABA infusion. Our results show an immediate inhibitory effect of GABA on PRL release and this effect disappeared when GABA was removed. Similar results were reported on $\alpha-\mathrm{MSH}$ release in the toad, Xenopus laevis, where GABA only induced inhibition on either intact intermediate lobes or dispersed pars intermedia cells (Verburg-van Kemenade et al. 1986, 1987). However, GABA was also shown to have biphasic effects on hormone release: in the frog and in the rat, GABA stimulates release for several minutes before inhibiting the secretory process (Tomiko et al. 1983; Tonon et al. 1986). Thus, GABA actions on PRL release in rainbow trout seem to be similar to what was described in the toad where Verburg-van Kemenade et al. (1987) concluded that this inhibitory action was mediated mainly by GABAb receptors. Whereas we were unable to observe any significant effect of baclofen, a GABAb receptor agonist, on PRL secreted by peri- 
fused pituitary fragments, this agonist had strong inhibitory effect on PRL cells in primary culture. This suggests the possible involvement of GABAb receptors in the inhibitory action of GABA. GABAa receptors appeared also to be involved in the action of GABA on perifused pituitary fragments. A GABAa agonist, 3APS, mimicked the inhibitory effect of GABA. This effect of GABA could also be reversed by bicuculline, a specific antagonist of GABAa receptor. Occupancy of GABAa sites has also been suggested to induce inhibition of $\alpha$-MSH release in a frog (Tonon et al. 1989). Although both types of GABA receptors seem to be involved in the inhibition of PRL secretion in rainbow trout, further studies are needed to clarify their precise roles.

In conclusion, the present study demonstrates that GABA acts directly on pituitary cells to inhibit PRL secretion, thus supporting the view that this inhibitory neurotransmitter may be a putative modulator of PRL cell activity in rainbow trout.

\section{Acknowledgements}

We are indebted to Dr. H. Vaudry and Dr. M.C. Tonon, GREM, University of Rouen, France, for their support during this work.

\section{References cited}

Adjeroud, S., Tonon, M.C., Lamacz, M., Leneveu, E., Stoeckel, M.E., Tappaz, M.L., Cazin, L., Danger, J.M., Bernard, C. and Vaudry, H. 1986. GABA-ergic control of $\alpha$ melanocyte-stimulating hormone ( $\alpha$-MSH) release by frog neurointermediate lobe in vitro. Brain Res. Bull. 17: 717-724.

Apud, J.A., Cocchi, D., Locatelli, V., Masotto, C., Müller, E.E. and Racagni, G. 1989. Biochemical and functional aspects on the control of prolactin release by the hypothalamo-pituitary GABAergic system. Psychoneuroendocrinol. 14: 3-17.

Duvilanski, B.H., Seilicovich, A., Diaz, M. del C., Maines, V.M., Lasaga, M. and Debeljuk, L. 1985. Effect of GABA-T inhibitors on prolactin secretion in vitro. Eur. J. Pharmacol. 115: 65-69.

Enjalbert, A., Ruberg, M., Arancibia, S., Fiore, L., Priam, M. and Kordon, C. 1979. Independent inhibition of prolactin secretion by dopamine and $\gamma$-aminobutyric acid in vitro. Endocrinology 105: 823-826.

Follénius, E. 1972. Intégration sélective du GABA- ${ }^{3} \mathrm{H}$ dans la neurohypophyse du poisson téléostéen Gasterosteus aculeatus
L. Etude radioautographique. C. R. Acad. Sci. 275: 14351438.

Gonnet, F., Prunet, P., Tonon, M.C., Dubourg, P., Kah, O. and Vaudry, H. 1988. Effect of osmotic pressure on prolactin release in rainbow trout: in vitro studies. Gen. Comp. Endocrinol. 69: 252-261.

James, V.A. and Wigham, T. 1984. Evidence for dopaminergic and serotoninergic regulation of prolactin cell activity in the trout Salmo gairdneri. Gen. Comp. Endocrinol. 56: 231-239.

Kah, O., Dubourg, P., Martinoli, M.-G., Geffard, M. and Calas, A. 1987a. Morphological evidence for a direct neuroendocrine GABAergic control of the anterior pituitary in teleosts. Experientia 43: 300-302.

Kah, O., Dubourg, P., Martinoli, M.-G., Rabhi, M., Gonnet, F., Geffard, M. and Calas, A. 1987b. Central GABAergic innervation of the pituitary in goldfish: a radioautographic and immunocytochemical study at the electron microscope level. Gen. Comp. Endocrinol. 67: 324-332.

Le Goff, P., Weil, C., Valotaire, Y., Gonnard, J.F. and Prunet, P. 1992. Effect of somatostatin on prolactin in rainbow trout (Oncorhynchus mykiss) pituitary cells in primary culture. $\mathrm{J}$. Mol. Endocrinol. 9: 137-146.

Locatelli, V., Cocchi, D., Frigerio, C., Betti, R., KrogsgaardLarsen, P., Racagni, G. and Müller, E.E. 1979. Dual $\gamma$ aminobutyric acid control of prolactin secretion in the rat. Endocrinology 105: 778-785.

Loeffler, J.-P., Kley, N., Pittius, C.W., Almeida, O.F.X. and Höllt, V. 1986. In vivo and in vitro studies of GABAergic inhibition of prolactin biosynthesis. Neuroendocrinology 43 : 504-510.

McCann, S.M., Vijayan, E., Negro-Vilar, A., Mizunuma, H. and Mangat, H. 1984. Gamma aminobutyric acid (GABA), a modulator of anterior pituitary hormone secretion by hypothalamic and pituitary action. Psychoneuroendocrinol. 9: 97-106.

Nistri, A. and Constani, A. 1979. Pharmacological characterization of different types of GABA and glutamate receptors in vertebrates and invertebrates. Prog. Neurobiol. 13: 117-235.

Prunet, P., Boeuf, G. and Houdebine, L.M. 1985. Plasma and pituitary prolactin levels in rainbow trout during adaptation to different salanities. J. Exp. Zool. 235: 187-196.

Racagni, G., Apud, J.A., Locatelli, V., Cocchi, D., Nistico, G., Di Giorgio, R.M. and Müller, E.E. 1979. GABA of CNS origin in the rat anterior pituitary inhibits prolactin secretion. Nature, Lond. 281: 575-578.

Racagni, G., Apud, J.A., Cocchi, D., Locatelli, D. and Müller, E.E. 1982. GABAergic control of anterior pituitary hormone secretion. Life Sciences 31: 831-838.

Tomiko, S.A., Taraskevich, P.S. and Douglas, W.W. 1983. Pharmacological and ionic features of $\gamma$-aminobutyric acid receptors influencing electrical properties of melanotrops isolated from the rat pars intermedia. Nature, Lond. 299: 733-734.

Tonon, M.C., Adjeroud, S., Lamacz, M., Louiset, E., Danger, J.M., Desrues, L., Cazin, L., Nicolas, P. and Vaudry, H. 1989. Central-type benzodiazepines and the octadecaneuropeptide modulate the effects of GABA on the release of $\alpha$ 
melanocyte-stimulating hormone from frog neurointermediate lobe in vitro. Neuroscience 31: 485-493.

Verburg-van Kemenade, B.L.M., Jenks, B.G. and Driessen, A.G. 1986. GABA and dopamine act directly on melanotropes of Xenopus to inhibit MSH secretion. Brain Res. Bull. 17: $697-704$.

Verburg-van Kemenade, B.M.L., Jenks, B.G., Lenssen, F.J.A. and Vaudry, H. 1987. Characterization of $\gamma$-aminobutyric acid receptors in the neurointermediate lobe of amphibian Xenopus laevis. Endocrinology 120: 622-628.

Weil, C., Hansen, P., Hyan, D., Le Gac, F., Breton, B. and
Crim, L. 1986. Use of pituitary cells in primary culture to study the regulation of gonadotropin hormone $(\mathrm{GtH})$ secretion in rainbow trout: setting up and validating the system as assessed by its responsiveness to mammalian and salmon gonadotropin releasing hormone. Gen. Comp. Endocrinol. 62: 202-209.

Wigham, T., Nishioka, R.S. and Bern, H.A. 1977. Factors affecting in vitro activity of prolactin cells in the euryhaline teleost Sarotherodon mossambicus. Gen. Comp. Endocrinol. 32: 120-131. 